\title{
THE EFFECT OF ALTITUTDE ON THE PRESENCE OF PLANT SPECIES IN STANDS FOR JUNIPERUS L. PLANT SPECIES ON KOPAONIK
}

\author{
Predrag Vasić $^{1 *}$, Tatjana Jaksić ${ }^{1}$, Nikola Đukić ${ }^{1}$ \\ ${ }^{1}$ Faculty of Natural Sciences and Mathematics, University of Piština, Kosovska Mitrovica, Serbia.
}

\begin{abstract}
In this paper we present an assessment of the altitude effect on the plant species presence in different plant communities - the species of Juniperus genus (Juniperus communis L., Juniperus oxycedrus L. and Juniperus sibirica Burgsdorf) on Kopaonik Mountain. Two juniper species (Juniperus communis and Juniperus oxycedrus) were recorded at altitudes ranging from $420 \mathrm{~m}$ to $1420 \mathrm{~m}$, while the third species Juniperus sibirica was found at an altitude of $2100 \mathrm{~m}$. It was
\end{abstract}

determined that the plant communities with the presence of species of the Juniperus genus differ in botanical terms at different altitudes. It was found that there are plant species in certain communities that are present only at some altitudes, while others were present at almost all altitudes. The species of Hypericum perforatum $\mathrm{L}$. is recorded in all of plant communities surveyed that proves its best adaptation to the conditions at different altitudes.

Keywords: Kopaonik Mountain, altitude, botanical composition, plant communities, Juniperus L., Hypericum perforatum L.

\section{INTRODUCTION}

Mountain regions are ideal for describing and studying the environmental responses of plant communities (Naqinezhad et al., 2009).

Kopaonik Mountain is located in the central part of the Balkan Peninsula and extends from northwest to southeast (NW-SE), between $20^{\circ} 35^{\prime}$ and $21^{\circ} 18^{\prime}$ of east longitude and $42^{\circ} 43^{\prime}$ and $43^{\circ} 23^{\prime}$ of north latitude. On the western side, Kopaonik massif is separated from geologically similar Rogozna and Golija with the valleys of the Ibar and Sitnica rivers. From the north, Kopaonik is separated with the valley of Jošanica River from the identical geological massif of Željina Mountain, and the whole area (KopaonikŽeljin) is bounded with the depression of the Morava River basin. From the South and Southwest the Lab River separates Kopaonik from Kosovo depression basin. The upper parts of the Rasina and Toplica rivers can be geographically regarded as the eastern border of Kopaonik massif (Gavrilović, 1979).

In terms of structure and morphology, the largest part of Kopaonik, especially its western part belongs to the so-called zone of internal Dinarides that was formed during the Alpine orogeny. The eastern parts of the Kopaonik massif are integral parts of the Serbian-Macedonian mass, and their basic geomorphological characteristics originated from hercin orogenesis, which means that they were morphologically shaped before the western part (Vasović, 1988).

Kopaonik mountain is extremely complex in geological terms. It is composed of three basic types of rocks: sediments, igneous and metamorphic rocks.

Kopaonik is characterized by multiple types of soil resulting by interaction of the relief, climate and vegetation over a longer period of time.

At lower altitudes, up to $1000 \mathrm{~m}$, siorezem, organogenic and siliceous soil, as well as Hum siliceous soil dominate. Siorezems are extremely shallow soil up to 20 inches deep. It can be found on steep slopes of sparse forests or poor pastures. Humus siliceous soil is a special type of fertile soil and it is formed at neutral, basic and acidic siliceous rocks. This type of soil is of relatively low productivity. Forests and pastures develop on it.

Brown and sour brown soils are dominant at altitudes above $1000 \mathrm{~m}$. They are formed on acid silicate rocks, slightly inclined slopes and plateaus. Acid brown soil can be relatively deep, while on the prominent ridges and slopes it can be more shallow and prone to erosion. Kopaonik land is suitable for forests and pastures development. 
Kopaonik has great elevation gradient, starting from the base, to its highest peaks. It can be divided into six high altitude climatic zones:

1. The first zone is dominated by thermophilic oak forests of Quercum frainetto species. This is the zone with dry, warm and mountain climate of sub-Mediterranean character. It stretches from the foothills up to $750 \mathrm{~m}$ on the northern, and up to $1050 \mathrm{~m}$ on the southern exposures. The average temperature of this zone is about $11^{\circ} \mathrm{C}$, and the average annual percipitation is about $787 \mathrm{~mm}$ of rainfall.

2. The second zone is a zone of gradual transformation into mountain climate. The presence of sessile oak forests, ie. vegetation type Quercum petrae-cerris is characteristic. It is located at an altitude of $1050-1150 \mathrm{~m}$ in the southern and 750-1000 $\mathrm{m}$ in the northern exposures. The average annual temperature of this zone is about $7.2{ }^{0} \mathrm{C}$, and the average annual precipitation is about $800 \mathrm{~mm}$ of rainfall.

3. The third zone is a zone of lower and middle temperate mountain climate. Vegetation is represented by beech and beech-fir forests of Fagion moesiacae type. The zone extends at an altitude of 1150-1550 m, on the southern and 1000-1500 $\mathrm{m}$ on the northern exposures. The average annual temperature of this zone is about $5^{\circ} \mathrm{C}$, the mean annual precipitation is about $827 \mathrm{~mm}$ of rainfall.

4. The fourth zone represents the area where the mountain climate is sharper and vegetation is dominated by pure spruce forests from Vaccinioo-Piceion type. It stretches between 1550 and $1750 \mathrm{~m}$ above sea level on the southern and 1500 and $1700 \mathrm{~m}$ on the northern exposure.

The annual average temperature is around $4^{0} \mathrm{C}$ and the average annual precipitation is about $857 \mathrm{~mm}$ of rainfall.

5. The fifth zone is in the zone of harsh subalpine climate. The vegetation type is made of communities of subalpine bushes of Juniperion Vaccinion myrtilli. They are located in the area between 1750 - $1950 \mathrm{~m}$ on the southern and $1700-1950 \mathrm{~m}$ on the northern exposures. The temperature of this zone on average is $3^{0} \mathrm{C}$, and the annual precipitation is $870 \mathrm{~mm}$.

6. The sixth zone is a zone that is covered by pre alpine harsh climate. The vegetation of this pre alpine climate consists of the high mountain pastures and mountain pastures, from Poion violaceae type. They are located in the zone above $1950 \mathrm{~m}$ above the sea level. Annual temperatures prevailing in these areas rarely rise above $2^{0} \mathrm{C}$, while the average amount of annual precipitation is about $883 \mathrm{~mm}$ of rainfall.

\section{THEORETICAL PART}

Vegetation distribution in mountain landscapes is characterized by spatially heterogeneous environmental conditions concerning climate, soil and geology as well as frequency and intensity of disturbance (Karkaj et al., 2012).

One important factor is altitude which has a strong influence on the vegetation structure. Impact of altitude to floristic composition have been considered as the subject of numerous studies ((Lomolino, 2001), (Naqinezhad et al., 2009), (Karkaj et al., 2012)). Altitudinal gradients are regarded as the most powerful ecological element which affects the natural vegetation structure.

Altitude presents an important orographic factor that affects the modification of various climates and soils, (Vasić et al., 2008) and therefore the species richness and the vegetation structure.

Temperature and relative humidity are the most important factors that determine the extent to which plants are present.

With increasing altitude the air becomes less thin and fresh, reflecting the solar radiation and temperature regime habitats. Proper temperature drops (for every $100 \mathrm{~m}$ above sea level, the temperature drops to $0,58^{0} \mathrm{C}$ ) (Vasić et al., 2008).

With altitude increase the air becomes less thin and fresher, reflecting the solar radiation and temperature regime of a habitat. The temperature drops (for every $100 \mathrm{~m}$ above the sea level, the temperature drops to $0,58^{0} \mathrm{C}$ ) (Vasić et al., 2008).

With the sea level increase, the relative humidity also rises due to the ascending air currents that send water vapor high into the air (Vasić, 2012). 
Plants that inhabit different altitudes are extremely efficient and cost-effectively customized to survive in a changing climate.

\section{EXPERIMENTAL PART}

\subsection{Material and methods}

The research in this paper was done in the period from 2015 to 2016. The list of flora is made up of the species given in an alphabetical order. The species presented in this paper include the plant communities in which species of Juniperus genus (Juniperus communis, J. and J. oxycedrus sibirica) were recorded at different altitudes $(470 \mathrm{~m}, 630 \mathrm{~m}, 830 \mathrm{~m}, 1030 \mathrm{~m}$, $1230 \mathrm{~m}, 1430 \mathrm{~m}$, and $2100 \mathrm{~m})$.

The plant material was determined using a Serbian flora key (Josifović, 1970-1986), and a nomenclature of plant species is customized to a flora of Europe
(Tutin, 1964-1980, 1993) and IOPI databases (International Organisation for Plant Information).

\subsubsection{Synthesis}

The subject of study in this paper is the presence of plants at different altitudes in the plant communities with the appearance of the genus Juniperus species ( $J$. communis, J. oxycedrus and J. sibirica). Two species of juniper (Juniperus communis and Juniperus oxycedrus) were found at altitudes from $420 \mathrm{~m}$ to 1420 $\mathrm{m}$, while the third species, Juniperus sibirica, was found at an altitude of $2100 \mathrm{~m}$. It should be noted that the species Juniperus communis and Juniperus oxycedrus could be found together up to $1420 \mathrm{~m}$ above sea level, but as the altitude increased these two species were less present because of the increasing negative anthropogenic impact on them (logging and deforestation).

Table 1. The presence of plant species in the plant communities with a dominance of species of the Juniperus genus.

\begin{tabular}{|c|c|c|c|c|c|c|c|}
\hline & $470 \mathrm{~m}$ & $630 \mathrm{~m}$ & $830 \mathrm{~m}$ & $1030 \mathrm{~m}$ & $1230 \mathrm{~m}$ & $1430 \mathrm{~m}$ & $2100 \mathrm{~m}$ \\
\hline Achillea millefolium $\mathrm{L}$. & + & - & + & + & + & + & - \\
\hline Acinos alpinus (L.) Moench & - & - & + & - & - & - & - \\
\hline Agrimonia eupatoria Ledeb. & - & + & - & - & - & - & - \\
\hline Agrostis stolonifera $\mathrm{L}$. & - & - & - & - & - & + & + \\
\hline Anagallis foemina Miller & - & - & + & - & - & - & - \\
\hline Artemisia vulgaris L. & - & + & - & - & - & - & - \\
\hline Asperula cynanchica $\mathrm{L}$. & + & - & + & - & - & - & - \\
\hline Astragalus onobrychis L. & - & - & + & - & - & - & - \\
\hline Bupleurum veronense Turra & + & - & - & - & - & - & - \\
\hline Calamintha vulgaris (L.) Druce & - & + & - & - & - & - & - \\
\hline Campanula patula $\mathrm{L}$. & - & - & - & - & - & + & - \\
\hline Carduus acanthoides L. & - & + & - & - & - & - & - \\
\hline Carlina vulgaris $\mathrm{L}$. & - & - & - & + & - & + & - \\
\hline Centaurea jacea $\mathrm{L}$. & - & - & - & - & + & - & - \\
\hline $\begin{array}{l}\text { Centaurea scabiosa L. } \\
\text { Centaurea alba L. subsp. splendens (L.) }\end{array}$ & - & + & - & - & - & - & - \\
\hline Arcangeli & - & - & + & - & - & - & - \\
\hline Centaurea biebersteinii DC. & + & + & - & + & - & - & - \\
\hline Centaurium erythraea Rafin. & - & - & - & + & - & - & - \\
\hline Cerastium caespitosum Gilib. & - & - & - & - & - & - & + \\
\hline Chamaespartium sagittale (L.) P. Gibbs & - & - & - & - & + & - & - \\
\hline Cirsium eriophorum (L.) Scop. & - & + & - & + & + & + & + \\
\hline Cornus mas L. & - & + & - & - & - & - & - \\
\hline Coronilla varia $\mathrm{L}$. & + & + & - & - & - & - & - \\
\hline Crataegus monogyna Jacq. & + & - & - & - & - & - & - \\
\hline Cuscuta sp. & - & + & - & - & - & - & - \\
\hline
\end{tabular}

\section{Biology}




\begin{tabular}{|c|c|c|c|c|c|c|c|}
\hline & $470 \mathrm{~m}$ & $630 \mathrm{~m}$ & $830 \mathrm{~m}$ & $1030 \mathrm{~m}$ & $1230 \mathrm{~m}$ & $1430 \mathrm{~m}$ & $2100 \mathrm{~m}$ \\
\hline Cytisus jankae Velen. & - & - & + & - & - & - & - \\
\hline Dactylis glomerata $\mathrm{L}$. & - & - & - & - & - & - & + \\
\hline Daucus carota $L$. & - & + & - & - & - & - & - \\
\hline Dianthus cruentus Griseb. & - & - & + & - & - & - & - \\
\hline Digitalis laevigata Waldst. \& Kit. & - & + & - & - & - & - & - \\
\hline Dorycnium herbaceum Vill. & - & + & - & + & - & - & - \\
\hline Eryngium campestre $\mathrm{L}$. & + & + & - & - & + & - & - \\
\hline Euphorbia amygdaloides $\mathrm{L}$. & - & - & - & + & - & - & - \\
\hline Euphorbia cyparissias L. & + & - & - & - & + & - & - \\
\hline Euphrasia stricta D. Wolff ex J. F. Lehm. & - & - & - & + & - & - & - \\
\hline Fagus moesiaca (K.Maly) Czecz. & - & - & - & - & - & + & - \\
\hline Fragaria vesca $\mathrm{L}$. & + & + & - & - & + & + & + \\
\hline $\begin{array}{l}\text { Galium verum } \mathrm{L} . \\
\text { Gentianella austriaca (A. \& J. Kerner) J. }\end{array}$ & - & - & - & + & + & - & - \\
\hline Holub & - & - & - & - & - & - & + \\
\hline Genista januensis Viv. & - & - & - & - & - & + & + \\
\hline Geranium columbinum $\mathrm{L}$. & - & - & + & - & - & - & - \\
\hline Gnaphalium sylvaticum $\mathrm{L}$. & - & - & - & - & - & + & - \\
\hline Heliantheтит питтиlarium (L.) Miller & - & + & - & + & + & - & - \\
\hline Helleborus odorus Waldst. \& Kit. & - & + & - & + & - & + & - \\
\hline Hieracium hoppeanum Schult. & - & - & - & + & + & + & - \\
\hline Hieracium pilosella $\mathrm{L}$. & + & - & + & - & - & - & - \\
\hline Hypericum perforatum $\mathrm{L}$. & + & + & + & + & + & + & + \\
\hline Juniperus communis $\mathrm{L}$. & + & + & + & + & + & + & - \\
\hline Juniperus oxycedrus $\mathrm{L}$. & + & + & + & + & + & + & - \\
\hline Juniperus sibirica Burgdsdorf. & - & - & - & - & - & - & + \\
\hline Lathyrus sp. & - & + & - & - & - & - & - \\
\hline Leontodon hispidus L. & - & - & + & + & + & + & - \\
\hline Linaria vulgaris Miller & - & + & - & - & - & - & - \\
\hline Linum catharticum L. & - & - & - & - & + & - & - \\
\hline Linum hologynum Rchb. & - & - & - & - & + & - & - \\
\hline $\begin{array}{l}\text { Lotus corniculatus L. } \\
\text { Luzula luzuloides (Lam.) Dandy \& }\end{array}$ & - & + & - & - & - & + & - \\
\hline Wilmott & - & - & - & - & - & + & - \\
\hline Medicago prostrata Jacq. & - & - & + & - & - & - & - \\
\hline Nardus stricta L. & - & - & - & - & - & + & - \\
\hline Onobrychis viciifolia Scop. & + & - & - & - & - & - & - \\
\hline $\begin{array}{l}\text { Ononis spinosa L. } \\
\text { Petrorhagia prolifera (L.) P. W. Ball \& }\end{array}$ & + & + & - & - & + & - & - \\
\hline Heywood & - & + & - & - & - & - & - \\
\hline Petrorhagia saxifraga (L.) Link & + & - & + & + & - & - & - \\
\hline Phleum phleoides (L.) Karsten & - & - & - & - & + & - & - \\
\hline Picris hieracioides $\mathrm{L}$. & + & + & - & - & - & - & - \\
\hline Pimpinella saxifraga $\mathrm{L}$. & - & - & - & - & + & - & - \\
\hline Plantago lanceolata $\mathrm{L}$. & + & - & - & - & + & - & - \\
\hline Plantago media $\mathrm{L}$. & - & + & - & + & + & - & - \\
\hline Poa cenisia All. & - & + & - & - & - & - & - \\
\hline
\end{tabular}




\begin{tabular}{|c|c|c|c|c|c|c|c|}
\hline & $470 \mathrm{~m}$ & $630 \mathrm{~m}$ & $830 \mathrm{~m}$ & $1030 \mathrm{~m}$ & $1230 \mathrm{~m}$ & $1430 \mathrm{~m}$ & $2100 \mathrm{~m}$ \\
\hline Polygala comosa Schkuhr & - & + & ـ & + & + & - & - \\
\hline Potentilla arenaria Borkh. & + & + & + & - & + & - & - \\
\hline Potentilla argentea $\mathrm{L}$. & + & - & - & - & - & - & - \\
\hline $\begin{array}{l}\text { Potentilla heptaphylla L. subsp. australis } \\
\text { (Krašan ex Nyman) Gams }\end{array}$ & - & - & - & + & - & - & - \\
\hline Primula veris $\mathrm{L}$. & - & - & - & + & - & - & - \\
\hline Prunella laciniata $(\mathrm{L}.) \mathrm{L}$ & - & - & - & + & + & - & - \\
\hline Prunella vulgaris $\mathrm{L}$. & - & - & - & + & - & - & - \\
\hline Pteridium aquilinum (L.) Kuhn. & - & - & - & + & - & - & - \\
\hline Ranunculus bulbosus $\mathrm{L}$. & - & - & - & - & + & - & - \\
\hline Rubus praecox Bertol. & + & - & - & - & - & - & - \\
\hline Rubus ideaus $\mathrm{L}$. & - & + & - & - & - & - & - \\
\hline Rumex acetosella L. & - & - & - & - & - & + & - \\
\hline Rumex crispus $\mathrm{L}$. & - & - & + & - & - & - & - \\
\hline Rumex sanguineus L. & - & - & - & - & - & - & + \\
\hline Scabiosa argentea $\mathrm{L}$. & - & + & - & - & - & - & - \\
\hline Salvia amplexicaulis Lam. & - & + & - & - & - & - & - \\
\hline Salvia verticillata $\mathrm{L}$. & + & - & + & - & - & - & - \\
\hline Sanguisorba minor Scop. & + & + & - & + & - & - & - \\
\hline Scabiosa columbaria $\mathrm{L}$. & - & - & - & + & - & + & + \\
\hline $\begin{array}{l}\text { Sedum sexangulare L. } \\
\text { Senecio squalidus L. subsp. rupestris }\end{array}$ & - & + & - & - & - & - & - \\
\hline (Waldst. \& Kit.) Greuter & - & - & - & - & + & + & - \\
\hline Silene sendtneri Boiss. & - & - & - & - & - & + & - \\
\hline Stachys аппиа (L.) L. & - & - & + & - & - & - & - \\
\hline Stachys recta $\mathrm{L}$. & - & - & + & - & - & - & - \\
\hline Stachys scardica (Griseb.) Hayek & - & - & - & + & - & - & - \\
\hline Stellaria graminea $\mathrm{L}$. & - & - & - & - & - & + & + \\
\hline Taraxacum officinale Weber & - & - & - & - & - & - & + \\
\hline Teucrium chamaedrys $\mathrm{L}$. & + & + & - & - & - & - & - \\
\hline Teucrium montanum $\mathrm{L}$. & + & - & + & + & - & - & - \\
\hline Thymus sp. & + & + & - & + & + & - & + \\
\hline Trifolium ochroleucon Hudson & - & - & - & + & - & - & - \\
\hline Trifolium patens Schreber & - & - & - & + & - & + & - \\
\hline Trifolium pratense $\mathrm{L}$. & - & + & + & - & - & + & + \\
\hline Tussilago farfara $\mathrm{L}$. & - & - & - & - & - & - & + \\
\hline Verbascum sp. & - & - & + & - & - & + & + \\
\hline Viola tricolor $\mathrm{L}$. & - & - & + & - & - & - & - \\
\hline Xerantheтит аппиит L. & + & + & - & - & - & - & - \\
\hline
\end{tabular}

\section{RESULTS AND DISCUSSION}

It was found that there are plants species present only at certain altitudes, while others are present at almost all altitudes as it can be observed from the table (Table. 1).
Plant species that occur only at one altitude are:Acinos alpinus (830 m), Agrimonia eupatoria (630 $\mathrm{m})$, Anagallis foemina $(830 \mathrm{~m})$, Artemisia vulgaris $(630 \mathrm{~m})$, Astragalus onobrychis $(830 \mathrm{~m})$, Calamintha vulgaris $(630 \mathrm{~m})$, Centaurium erythraea $(1030 \mathrm{~m})$, 
Comus mas $(630 \mathrm{~m})$, Dactylis glomerata $(2100 \mathrm{~m})$ and other.

Plant species that occur only at two altitudes: Agrostis stolonifera (1430 m and $2100 \mathrm{~m})$, Asperula cynanchica (470 m and $830 \mathrm{~m}$ ) Carlina vulgaris (1030 $\mathrm{m}$ and $1430 \mathrm{~m})$, Coronilla varia $(470 \mathrm{~m}$ and $630 \mathrm{~m})$, Dorycnium herbaceum $(630 \mathrm{~m}$ and $1030 \mathrm{~m})$, Euphorbia cyparissias (470 m and $1230 \mathrm{~m})$ Prunella laciniata $(1030 \mathrm{~m}$ and $1230 \mathrm{~m})$, Salvia verticillata (470 $\mathrm{m}$ and $630 \mathrm{~m})$ and other.

Plant species that can be seen at more than two altitudes are: Achillea millefolium $(470 \mathrm{~m}, 830 \mathrm{~m}$, $1030 \mathrm{~m}, 1230 \mathrm{~m}$ and $1430 \mathrm{~m})$, Cirsium eriophorium $(470 \mathrm{~m}, 1030 \mathrm{~m}, 1230 \mathrm{~m}, 1430 \mathrm{~m}$ and $2100 \mathrm{~m})$, Fragaria vesca $(470 \mathrm{~m}, 630 \mathrm{~m}, 1230 \mathrm{~m}, 1430 \mathrm{~m}$ and $2100 \mathrm{~m}$ ), Leontodon hispidus (830, m, $1030 \mathrm{~m}, 1230$, m, $1430 \mathrm{~m})$, Ononis spinosa $(470 \mathrm{~m}, 630 \mathrm{~m}$ and 1230 m) and other.

It was noted that the plant species Hypericum perforatum, is recorded in all of plant communities surveyed that proves its best adaptation to the conditions at different altitudes.

\section{CONCLUSION}

In this paper we showed that plant species inhabit habitats of different altitudes and the plants respond differently related to various soil factors in investigated communities. Some plants are adapted on various types of land and climate, such as Hypericum perforatum. Other species have adapted to live in the narrow range of temperature and humidity, and therefore inhabit only small areas where they 'he been specialized on certain properties of the soil at different altitudes of the mountain. Plant as: Acinos alpinus (830), Agrimonia eupatoria(630), Anagallis foemina Mili (830) live in habitats on certain altitude, while Agrostis alba (1430 и 2100), Carlina vulgaris(130 и 1430) and Achillea millefolium (470,1030, 1230 и1430), Cirsium eriophorum (470, 1030, 1230 и1430) can be found on two or more different altitudes.

\footnotetext{
*E-mail: predrag.vasic@pr.ac.rs
}

\section{ACKNOWLEDGEMENT}

This paper was written under the project of the Ministry of Education, Science and Development of Republic of Serbia OI 171025.

\section{REFERENCES}

Gavrilović C., 1979. Хипсонометрија површине рељефа Копаоника. Зборник радова географског института ПМФ у Београду, 26. Београд.

IOPI databases. Retrieved from http://plantnet.rbgsyd.nsw.gov.au/iopi/iopihome.htm

Josifović, M., \& ed., 1970. Flora of SR Serbia IX.Belgrade, Serbia: SANU. In Serbian.

Karkaj, E.S., Motamedi, J., Akbarlou, M., \& Alijanpour, A. 2012. Floristic Structure and Vegetation Composition of Boralan Mountainous Rangelands in North-Western Azerbaijan, Iran., pp. 697-706.

Lomolino, M.V. 2001. Elevation gradients of speciesdensity: Historical and prospective views. Global Ecology and Biogeography, 10, pp. 3-13.

Naqinezhad, A., Jalili, A., Attar, F., Ghahreman, A., Wheelerc, B.D., Hodgsonc, J.G., . . Maassoumi, A. 2009. Floristic characteristics of the wetland sites on dry southern slopes of the Alborz Mts. Iran: The role of altitude in floristic composition. Flora, 204, pp. 254-269.

Tutin, T.G., Heywood, V.H., Burges, N.A., Moore, D.M., Valentine, D.H., Walters, S.M., . . . eds., 1964. Flora Europaea, I-V.London: Cambridge University Press. 1964-1980.

Vasić, P. 2012. Morfološko anatomska građa listova roda Juniperus sa različitih nadmorskih visina Kopaonika.Prirodno-matematički fakultet Univerziteta u Prištini sa privremenim sedištem u Kosovskoj Mitrovici. Doktorska disertacija.

Vasić, P., Labus, N., Topuzović, M., \& Dubal, D. 2008. Morphological-anatomical characteristics of Juniper (Juniperus sibirica) from the area of mountain Kopaonik. Заштита природе, 59(1-2), pp. 115-120.

Vasić, P., Topuzović, M., Labus, N., \& Dubak, D. 2008. Morphological-anatomical characteristics of Commun Juniper (Juniperus communis) from the area of mountain Kopaonik. Natura Montenegrina, 7(3), pp. 97-107.

Vasović, M. 1988. Kopaonik.Beograd: Stručna knjiga. Васовић М., . Копаоник.Београд: СГД. Посебно издање, књига 65. 